\title{
IAMJ
}

INTERNATIONAL

AYURVEDIC

MEDICAL JOURNAL

\section{GUDUCHI: A BOON TO CURE JWARA}

\section{Veena Naik $^{1}$, Subrahmanya $\mathbf{P}^{2}$}

${ }^{1}$ Assistant Professor, Department of Dravya Guna Vijnana, Government Ayurveda Medical College, Mysore, Karnataka, India

${ }^{2}$ Professor \& Head, Department of P G Studies in Dravya Guna Vijnana, Alva's Ayurveda Medical College, Moodubidre, Karnataka, India

Corresponding Author: veenanaik48@gmail.com

\section{https://doi.org/10.46607/iamj3109102021}

(Published Online: October 2021)

Open Access

(C) International Ayurvedic Medical Journal, India 2021

Article Received: 06/09//2021 - Peer Reviewed: 22/09/2021 - Accepted for Publication: 24/09/2021

\section{Check for updates}

\section{ABSTRACT}

Ayurveda is the science that talks about the longevity of life, maintenance of health and destroying the disease. Amongst diseases, Jwara (Fever) is the first to affect mankind which comes in tamas form at the time of birth and death. It is crucial among all diseases as it affects not only human beings but also all living creatures. Ayurveda explains about many Dravyas (substance) to reduce fever. Amongst them Guduchi [Tinospora Cordifolia (Willd.) Miers] of family Menispermaceae, is a climbing shrub found throughout tropical India. The plant is having its reference in most of the Ayurveda literature, which is indicated in Jwara, Vataraktha (Gout) Kushtha (skin Diseases), Prameha (diabetes)etc. Presently Ayurveda has come close to humans that it has become a human science. Through this paper an effort is made to know more about the Dravya Guduchi, with its mode of action on Jwara with relevance to Dravya Prabhava, Guna Prabhava and Dravya Guna Prabhava

Keywords: Ayurveda, Guduchi, Jwara 


\section{INTRODUCTION}

Ayurveda which is Upaveda of Atharvaveda explains the longevity of life span with the maintenance of healthy condition and destroying the ailments. It also explains about Ahaara Vihara and Achara to maintain health and longevity ${ }^{1}$. It is a science that is eternal ${ }^{2}$. It tells about many conditions about the diseased state as well as about healthy conditions of living creatures. About Jwara it has explained Nidaan, Purvarupa, Rupa, Samprapti and Chikitsa. Jwara is first described among all disorders as temperature or body heat is increased and is the first condition afflicting patients of somatic conditions. It is considered as the first manifested ailment (before the other diseases). According to various Acharyas, Jwara is originated from the anger of Lord Maheswara, and it takes away the life of living beings and all creatures, causes disturbance in the body, sense organs and mind, diminishes intellect, strength, complexion, pleasure, and enthusiasm, produces tiredness, exhaustion, confusion, and difficulty in intake of food and it brings unhappiness in the person, no other disease is so severe, complicated, and difficult in management as this. Acharya Sushruta has mentioned Jwara as the king of diseases ${ }^{3}$. A man comes into this world with Jwara and departs with it and it is such a difficult disease that gods and men could only withstand it.

The plant Guduchi botanically identified as [Tinospora Cordifolia (Willd.) Miers], belongs to the family Menispermaceae, is a climbing shrub found throughout tropical India. The vernacular names of Guduchi are Giloe, (Hindi), Gulwel (Marathi), Gilo (Gujrati), Golanca (Bengali), Tippateege (Telugu), Chindil-kadi (Tamil) and Amritha balli (Kannada). Its stem is bitter, astringent, pungent and has many properties which are used to cure burning sensation, fever, urinary diseases, cough, anaemia, jaundice, skin diseases, vata rakta, dyspnoea and worm infestation. Juice from the fresh plant is useful as a diuretic. Leaves are useful in jaundice. Guduchi is renowned in Ayurvedic therapeutics for its utility in the treatment of $J w a-$ $r a$ (fever).

In classical texts various preparations such as Guduchi Kalka, Ghrita and Swarasa are prepared from the stem of Guduchi is indicated for treating Jwara. It tends to grow even if it is cut and have properties to treat fever and are capable to prevent old age and disease and hence used as Rasayana. All its varieties are good febrifuge (Jwaranashini). Acharya Charaka in Charaka Samhita quoted it among the Agrya Dravyas (principal drugs) by attributing Grahi, Vatahara, Deepaniya, Kapha Raktahara and Vibandhahara ${ }^{4}$ properties and categorized under Medhya Rasayana. Acharya Sushruta highlighted Pitta and Kaphahara properties of Guduchi while Vagbhata emphasized its utility in Vatarakta.

Ayurvedic properties of Guduchi are ${ }^{5}$

Rasa (taste)- Katu (Pungent) Tikta (bitter), Kashaya (Astringent)

Guna (quality)- laghu(light),

Veerya(potency)- Ushna (having hot potency)

Vipaka (post-digestive effect)- Madhura

Doshaghnata -Tridoshashamaka (pacify all three aggravated Dosha)

Rogaghnata -Kushtha, Vatarakta, Netraroga, Trushna, Daha, Chhardi, Aruchi, Agnimandya, Shoola, Yakridvikara, Kamala, Amlapitta

Karma (action)- Agnideepaka (increase appetite), Pachana (Digestive), Rasayana (rejuvenating), Vayah Sthapana (anti-ageing), Trishna nigrahana (quenches thirst), Sangrahi (relieve polyuria), Medhya (nerve tonic), Balya (increase strength), Vrishya (aprodisiac), Chakshusya (eye tonic).

Dhatu (tissue)- Rasa (plasma), Rakta (blood), Mamsa (muscle), Meda (fat)

Chemical constituents of this plant's stem are rich in sesquiterpene tinocodifolin alkaloids (berberine, choline, magnoflorine, palmatine, tembetarine, magnoflorine, tinosporine, tetrahydropalmatine, isocolum Aim and Objectives:

- To understand the concept of Jwara.

- To study the conceptual effect of Guduchi in the treatment of Jwara.

\section{Materials and Methods:}

- Relevant Ayurvedic and modern textbooks.

- Previous Research Papers. 
- Various National or International journals or magazines.

\section{RESULTS AND DISCUSSION}

In any mode of action, one must know about Disease and Dravya perfectly. About disease, one must know Nidan, Samprapti, Rupa and Purvrupa in detail and about Dravya pharmacology must understand with Rasa, Guna, Virya, Vipak, prabhav and Karma Pharmacokinetics in Ayurveda
According to Charak, usually, the drug action of any Draya will depend upon either Rasa or Guna or Virya or Vipak or Prabhav ${ }^{6}$.

The absorption and fate of the drug is well explained by Charak while its journey inside the body each one of the pharmacologically active ingredients of the Dravya will supersede the other in the following or$\operatorname{der}^{7}$

Rasa $\rightarrow$ Vipaka $\rightarrow$ Virya $\rightarrow$ Prabhav

The fate of the four ingredients of drugs is well known to the ancient Acharyas

Raso nipate dravyanam

Viryam yavadadhiyasta nipatat cha upalabhyate

Vipakah karma nishtaya

Vishishta karmanam chaiva prabhav
Effect of rasa is perceived on contact with the tongue which is mainly local action Effect of virya assesses either when it is applied externally on the body or when it exhibits its activity on the receptor internally Is assessed after observing the final action of the metabolized ingredient of a drug The non-specific effects of a drug are stated to be due to Prabhav

Guna is a physical property that is seen in all other constituents

Jwara nidan- improper and excess administration of Snehadi Samshodhana Karma, various kinds of injury, suffering from diseases, exertion, depletion of Dhatus, improper digestion of food, change of habitat and natural characteristics of the seasons, abnormal delivery in women, during the production of milk brings disequilibrium state of Dosha

Flowchart of the pathogenesis of Jwara

Aggravated Dosha enters the Amashaya and influence Pachakagni accompanying the Rasa causing indigestion
Block the Srotas of Rasavaha and Swedavaha impairs the function of Agni and expel out the Agni from the site of
digestion and spreads to all over the body.
Shareeer santapa is rupa of Jwara

Samprapti Ghatak - DOSHA - Pitta Pradhana

Tridoshaja,

DUSHYA - Vata-Vyana, Pitta -Pachaka, Kapha-

Kledaka,

DUSHYA - Dhatu - Rasa, Updhatu - Twak,

Sharirikamala - Mutra and Purish,
Dhatumala - Kapha, Sweda, Pitta, AGNI - Jatharagni, Dhatwagni, Bhutagni, AGNIDUSHTI-Mandagni, SROTAS - Rasavaha, Swedavaha, Udakavaha ADHISTHANA - Sharir, Manas 


\section{Guduchi}

\begin{tabular}{|c|c|c|c|c|}
\hline & In Guduchi & Panchbhoutik composition & Effect on doshas & Karma \\
\hline \multirow[t]{3}{*}{ Rasa } & Katu & Vayu + Agni & Kapha decreases vata pitta increase & Agnideepan, Srotavivaran \\
\hline & Tikta & Vayu +Akash & $\begin{array}{l}\text { Pitta kapha decreases vata } \\
\text { increases }\end{array}$ & $\begin{array}{l}\text { Dahaprasamana, } \\
\text { naprasamana }\end{array}$ \\
\hline & Kashaya & Vayu + Prithvi & $\begin{array}{l}\text { Pitta kapha decreases vata } \\
\text { increases }\end{array}$ & Sangrahi, Jwarahara \\
\hline Guna & Laghu & Akash, Vayu, Agni & Kapha decrease and vata increases & Srotoshodhak and Laghupaka \\
\hline Virya & Ushna & Agni & Vatakapha increase pitta decreases & $\begin{array}{l}\text { Deepan pachan swedan, vila- } \\
\text { yana ashupaka }\end{array}$ \\
\hline Vipak & Madhur & Prithvi and Jala & Kapha increase vata pitta deceases & Dhatuposhan \\
\hline
\end{tabular}

\section{Mode of Action}

\begin{tabular}{|l|l|}
\hline In Dravya Guduchi & In Jwarit kaya \\
\hline Rasa- Tikta Katu kashaya & Acts over agni, Agnidipti \\
\hline Ushna -Virya & Pachan of aam, Rasvaha Swedavaha Srotas obstruction clear \\
\hline Madhur-Vipaak & Pitta samudbhuta disease Jwara madhur vipaak acts over pitta dosha \\
\hline Guna -Laghu & Produces Laghuta
\end{tabular}

\section{According to Charak}

Usually, the drug action of any Dravya will depend upon either Rasa or Virya or Vipak or Prabhav

Charak explained different modalities of drug action in the following way.

Which perform a particular activity is called Karma Which is means of performing the Karma is called Virya

The site of action is known as Adhikarana

The time taken for drug action is Kala

The activity through a specific pathway is known as Upaya

The result obtained through the effect of drug over the body is called Phala

With this view, only Charaka explained the drug may act either by means of natural property (dravya prab$h a v$ ) or by means of individual characteristics (guna prabhav) sometimes both may help together in drug action.

So,

Dravya-Guduchi

Karma- Agnideepan, Jwarahara

Virya - Ushna

Adhikarana- whole body, Amashaya
Kala - when Shareer Taapa is seen

Upaya- various measure like langhan, aam nirama condition is seen

Phala- Sweotpatti, Laghuta in body

Which perform an activity is karma, here it is about Jwarahara Karma is explained.

Karma (Jwarahara) is performed with the dravya (Guduchi).

\section{CONCLUSION}

Jwara is troublesome for both body and mind which can manifest firstly when Dosha, Dhatu and Mala any one of them gets vitiated. The main reason for the cause of Jwara is the formation of Ama (undigested food). To digest Ama, Langhana is said to be as the first line of treatment except in the fevers which were manifested because of Kshaya (emaciation), Vyadhikhyata (Vataja Jwara), Bhaya (fear), Krodha (angry), Kama (excess desire), Shoka (grief) and Shrama (excess tiredness) as it may worsen the condition. In the case of Tarun Jwara (Acute fever) decoction is not advised because it is difficult to conquer vitiated Dosha because of its Astringent taste. Hence any medicine must be taken after the consulta- 
tion of physicians. Medicine is given for the proper treatment of the disease in which Guduchi is one of them where the Dravya Guna Prabhav is seen, both Dravya Prabhav as well as Guna prabhav is attributed to treating Jwara.

\section{REFERENCES}

1. Charak Samhita of Agnivesa published by Choukambha orientalia Varanasi Year $2015 \mathrm{su}$ trasthana chapter 1 verse 53 page no 14

2. Charak Samhita of Agnivesa published by Choukambha orientalia Varanasi Year 2015 sutrasthana chapter 30 verse 27 page no 188

3. Sushruta samhita of Sushruta published by choukambha orientalia Varansi year 2019 uttaratantra chapter39 verse 10 page no 671

4. Charak Samhita of Agnivesa published by Choukambha orientalia Varanasi Year 2015 sutrasthana chapter 25 verse 40 page no 131

5. Bhavaprakash nighantu Shree Brahmashankar Shashtri published by Choukambha Samskrit samsthan Varanasi ninth Edition year 1999 page no 269

6. Charak Samhita of Agnivesa published by Choukambha orientalia Varanasi Year 2015 sutrasthana chapter 26 verse 71 page no 148

7. Charak Samhita of Agnivesa published by Choukambha orientalia Varanasi Year 2015 sutrasthana chapter 26 verse 72 page no 148

8. Charak Samhita of Agnivesa published by Choukambha orientalia Varanasi Year 2015 nidaansthana chapter 1 verse 20,23,26 page no 199-201

\section{Source of Support: Nil \\ Conflict of Interest: None Declared}

How to cite this URL: Veena Naik \& Subrahmanya P: Guduchi: A Boon To Cure Jwara. International Ayurvedic Medical Journal \{online\} 2021 \{cited October 2021\} Available from: http://www.iamj.in/posts/images/upload/2490_2494.pdf 